\title{
Oxygen kinetic isotope effects in selenate during microbial reduction
} \author{
Casanova $^{a *}$ \\ Addresses: \\ ${ }^{a}$ Department of Civil \& Environmental Engineering \\ Northeastern University \\ 400 Snell Engineering, Boston, Massachusetts, 02115, USA \\ Email: p.laresecasanova@neu.edu \\ Email: schellenger.a@husky.neu.edu \\ Email: a.onnis-hayden@neu.edu \\ ${ }^{b}$ Department of Plant and Soil Sciences \\ University of Delaware \\ 531 S College Ave., Newark, DE 19716 \\ Email: jaisi@udel.edu \\ *Corresponding Author: \\ Philip Larese-Casanova \\ Department of Civil \& Environmental Engineering \\ Northeastern University \\ 400 Snell Engineering, Boston, Massachusetts, 02115, USA \\ Phone: +1 617-373-2899; Fax: +1-617-373-4419 \\ Email: p.laresecasanova@neu.edu
}

Alexandra E. P. Schellenger, ${ }^{a}$ Annalisa Onnis-Hayden, ${ }^{a}$ Deb P.Jaisi, ${ }^{b}$ and Philip Larese-

Submitted to: Applied Geochemistry

Keywords: Selenium, reduction, oxygen isotope ratios, kinetic isotope effect, dissimilatory selenium reduction, Sulfurospirillum barnesii SES-3

(C) 2015. This manuscript version is made available under the Elsevier user license http://www.elsevier.com/open-access/userlicense/1.0/ 


\section{Abstract}

The redox cycling of selenium oxyanions, elemental selenium, and selenides within water resources has implications for Se bioavailability and ecotoxicity. Dual stable isotope analysis of Se and $\mathrm{O}$ may provide important information for interpreting environmental Se transformations. Stable Se isotope systematics within the Se redox cycle has been well characterized within the literature, however concomitant oxygen isotope composition requires additional investigation. This study reports the $\mathrm{O}$ isotope fractionation of selenate $\left(\mathrm{SeO}_{4}{ }^{2-}\right)$ during microbial reduction by the dissimilatory Sereducing bacterium Sulfurospirillum barnesii SES-3. Microbial reduction experiments were conducted under various conditions in order to investigate the range of ${ }^{18} \mathrm{O}$ enrichment factors $\left(\varepsilon_{O}\right)$ in selenate. The reduction of selenate to selenite coupled to the oxidation of lactate to acetate resulted in an ${ }^{18} \mathrm{O}$ kinetic isotope effect with $\varepsilon_{\mathrm{O}}$ values 1.5 $5.8 \%$. Greater ${ }^{18} \mathrm{O}$ enrichment was observed with increasing $\mathrm{pH}$, but no correlation was found between $\varepsilon_{O}$ and reduction rates, lactate availability, or cell density. $\varepsilon_{O}$ values from biotic reduction by $S$. barnesii here are significantly less than those observed for abiotic reduction with $\mathrm{Fe}(\mathrm{II})$-rich minerals reported in the literature, and this difference could be explained by a diffusion limitation during enzymatic reduction. Our results expand the isotope systematics of the selenium redox cycle and suggest $\varepsilon_{O}$ has potential usefulness as indicators for in situ selenate reduction. 


\section{Introduction}

Selenium (Se) within lakes, wetlands, and estuaries poses a concern because Se exposure may lead to Se bioaccumulation and toxic health effects in wildlife(Lemly, 1985; Lemly, 2002; Ohlendorf et al., 1986; Presser, 1994). Se presence in natural waters may arise from natural sources such as erosion from seleniferous soils or ores, or from anthropogenic inputs such as deposition from combustion or waste disposal from petroleum processing (Lemly, 2004; Mast et al., 2014; Tuttle et al., 2014). Consequently, considerable effort has been made to understand Se source identification, its transport through environmental compartments, and the biogeochemical processes that control its fate(Seiler et al., 1999).As part of these investigations, stable isotope analysis has been a particularly useful tool to interpret Se behavior in nature by providing a means to measure source-dependent isotopic signatures and to observe reaction-induced isotopic changes (Schilling et al., 2011a; Clark \& Johnson, 2010).

Interpretations of Se isotope measurements in nature have been supported by laboratory experiments that evaluate stable Se isotope systematics within the $\mathrm{Se}$ biogeochemical cycle(Johnson, 2004). Se may cycle among four redox states across the aqueous, solid, and gaseous phases. The dissolved oxyanions selenate $\left(\mathrm{Se}(\mathrm{VI}), \mathrm{SeO}_{4}{ }^{2-}\right)$, selenite ( $\mathrm{Se}(\mathrm{IV}), \mathrm{SeO}_{3}{ }^{2-}$ ), and biselenite ( $\mathrm{Se}(\mathrm{IV}), \mathrm{HSeO}_{3}{ }^{-}$) are mobile and more bioavailable, whereas elemental $\mathrm{Se}(\mathrm{Se}(0))$ and mineral and organic selenides ( $\mathrm{Se}(-\mathrm{II}))$ may remain fixed among soils and sediments, and biomethylated selenides may become volatilized. Fractionation of Se isotopes on the order of $\sim 3-12 \%$ have been shown to occur during microbial and mineralogical reduction of selenate to selenite and from 
selenite to elemental $\mathrm{Se}(\mathrm{Johnson}, 2004)$. This is caused by the preference for lighter $\mathrm{Se}$ isotopes during the $\mathrm{Se}-\mathrm{O}$ bond breaking and results in the products becoming isotopically lighter and the reactants becoming enriched with heavier Se isotopes. Smaller but significant enrichments ( $\sim 3$ to $-6 \%$, i.e. enriched in lighter isotopes) in methylselenide have been observed during biomethylation of selenate and selenite by fungi and soil, and fractionation extents were indicative of the Se oxyanion source(Schilling et al., 2011b; Schilling et al., 2013). Oxidation reactions of $\mathrm{Se}(0)$ to $\mathrm{Se}(\mathrm{IV})$ or $\mathrm{Se}(\mathrm{IV})$ to $\mathrm{Se}(\mathrm{VI})$ so far reveal little or no fractionation in Se isotopes(Johnson, 2004).

The present study and our previous work(Schellenger \& Larese-Casanova, 2013) contribute to Se oxyanion isotope systematics by expanding observations to include fractionations imprinted upon stable oxygen isotopes during redox reactions.The use of stable oxygen isotopes can be combined with Se isotope measurements for a dual isotopic analysis approach that may strengthen lines of evidence for Se oxyanion transformation or source identification. As is typical for light element fractionation, ${ }^{18} \mathrm{O} /{ }^{16} \mathrm{O}$ isotope ratios may provide a more sensitive measurement and therefore a larger fractionation compared to the heavier ${ }^{82} \mathrm{Se} /{ }^{76} \mathrm{Se}$ ratios owing to the greater percent mass difference ( $\sim 13 \%$ and $\sim 7 \%$, respectively). Like Se, a kinetic isotope effect (KIE)for O can be induced when the Se-O bond breaking reactions involving the Se oxyanions preferentially consume the oxyanions containing the lighter isotope (for instance $\mathrm{O}^{16}$ rather than $\left.\mathrm{O}^{18}\right)$, enriching the remaining reactant pool with the heavier isotope $\left(\mathrm{O}^{18}\right)$ similar to other oxyanions such as phosphate (Blake et al., 2005), nitrate (Kendall 1998), and sulfate (Turchynet al., 2010). This enrichment may be measured as long as the isotopes are preserved within the oxyanion and enriched selenate mixes back with the 
reservoir of bulk dissolved selenate.Although the oxygen isotopes of selenite readily equilibrate with water molecules and thus erase any enrichment for lighter isotopes(Okumura \& Okazaki, 1973a), selenate oxygen does not exchange isotopes within the $\mathrm{pH}$ range of natural waters (6-9), and may therefore be preserved within the water column or in transport(Okumura \& Okazaki, 1973b; Kaneko \& Poulson, 2012).The KIE associated with the oxygen isotope during mineralogical selenate reduction with the Fe(II) layered double hydroxide green rust has been identified(Schellenger \& LareseCasanova, 2013), and previous work has explored the KIE for the Se isotope during both mineralogical and microbial reduction of selenate(Clark \& Johnson, 2010; Johnson \& Bullen, 2003; Ellis et al., 2003; Herbel et al., 2000).

The objective of this work, therefore, is to examine how the microbial reduction process influences the stable oxygen isotope values of selenate oxyanions. Bacteria capable of coupling Se oxyanion reduction to organic matter oxidation have been observed within diverse soil, sediment, fresh water, and saline water environments. (Switzer Blum et al., 1998; Switzer Blum et al., 2001; Fan et al., 1998; Macy et al., 1993; Oremland et al., 1989; Stolz et al., 1999). Isolates have been identified across various genera, with notable species including Thaueraselenatis, Bacillus selenitireducens, Pseudomonasstutzeri, and Sulfirospirillum barnesiiSES-3, which are typically capable of dissimilatory reduction or cometabolism of several inorganic oxyanions as electron acceptors(Switzer Blum et al., 1998; Stolz et al., 1999; DeMollDecker \& Macy, 1993; Lortie et al., 1992; Oremland et al., 1994; Oremland et al., 1994; Macy et al., 1989; Macy et al., 1989; Maiers et al., 1988). The prevalence and flexibility of Se-respiring microorganisms in nature consequently allows for their harnessing for 
bioremediation of Se-contaminated sites under a wide range of natural conditions (Frankenberger \& Arshad, 2001), during which the processes of microbial Se oxyanion reduction to insoluble elemental Se or to volatile organic selenides plays an important role in lessening Se bioavailability. Mineralogical reduction to $\mathrm{Se}(0)$ by $\mathrm{Fe}(\mathrm{II})$ (Myneni et al., 1997), might occur only within Fe-rich, reducing subsurface environments(Christiansen et al., 2009), whereas microbial reduction may be more widespread. Stable isotope analysis of selenate during microbial reduction may assist in characterizing the prevailing modes of Se redox cycling in Se-impacted environments.

The goals of this work are (i) to identify whether microbial reduction induces a kinetic isotope effect for oxygen in selenateand produces a quantifiable enrichment factor $\left(\varepsilon_{0}\right)$ for the reaction, and (ii) to determine the range of observed $\varepsilon_{0}$ values as a function of microbial suspension conditions and determine if these $\varepsilon_{0}$ values differ from those of chemical reduction processes. Enzymatic reduction by selenate-respiring bacteria could be described to involve a selenate diffusion step to enzyme sites followed by electron transfer and reduction to selenite. The relative rates of selenate diffusion to reactive sites and reduction to selenite may influence the extent of $\mathrm{O}$ isotope fractionation, with any mass transfer limitation in microbial systems possibly leading to lower observable enrichments(Herbel et al., 2000), compared to chemical reduction by chloride green rust with no diffusion limitation(Schellenger \& Larese-Casanova, 2013). Such differences in element enrichments have been observed for chemical and microbial reduction of organic pollutants (e.g., (Liang et al., 2007)). If the observed difference is large enough oxygen isotopes may have a role to play in reactiondifferentiation in subsurface systems. This question has implications to whether both Se and $\mathrm{O}$ enrichment values can be used 
simultaneously in a dual KIE approach as indicators of subsurface selenate reduction and possibly as a distinct identifier of biological reduction in particular.

The anaerobic freshwater bacterium Sulfurospirillum barnesii SES-3 was chosen as a representative selenate-respiring microorganism for observing kinetic isotope effect in selenate oxygen. S. barnesii is an environmental opportunist, capable of using a number of electron acceptors to facilitate respiration including arsenate, thiosulfate, nitrate, and selenate, and thrives under neutral to slightly alkaline $\mathrm{pH}$ (Laverman et al., 1995), which are conditions similar to many surface or subsurface waters with elevated Se(Seiler et al., 1999).Like many Se reducing microbes, S. barnesii utilizes membrane bound enzymes to couple the reduction of selenate to selenite and $\operatorname{Se}(0)$ with the oxidation of organic carbon sources such as lactate(Oremland et al., 1994; Oremland et al., 1999). Finally, this strain has been shown previously to produce a measureable KIE in the Seisotopes when conducting this reduction at circumneutral $\mathrm{pH}(\mathrm{Herbel}$ et al., 2000). Because microbial isotope enrichment may be affected by reduction rate(Harrison \& Thode, 1958) and because microbial reduction rates may be affected by alterations in environmental conditions, we surveyed the ${ }^{18} \mathrm{O}-\mathrm{KIE}$ in cell suspensions under a range of geochemical conditions. Differences in $\mathrm{pH}$, cell density, and electron donor/acceptor ratios were evaluated for their effect on ${ }^{18} \mathrm{O}$ enrichment during reduction.

\section{Experimental Methods}

\subsection{Sulfurospirillum barnesii SES-3 cultivation}


Anoxic conditions were maintained for all cell growth and cell suspension experiments within a COY vinyl chamber with a $1 \% \mathrm{H}_{2}$ and $99 \% \mathrm{~N}_{2}$ atmosphere. All solutions were prepared with deionized water $(>18 \mathrm{M} \Omega)$ deoxygenated by boiling in an autoclave $\left(121^{\circ} \mathrm{C}\right)$ and immediately placed inside the anoxic chamber.

Sulfurospirillum barnesii SES-3 cells were purchased freeze-dried from the American Type Culture Collection (ATCC,Cat. No. 700032) and stored at $-80{ }^{\circ} \mathrm{C}$. A portion of these purchased cells were thawed and grown on the DSMZ-recommended growth medium (Medium 771 containing lactate as a carbon source and nitrate as a terminal electron acceptor, sterilized by autoclaving or sterile filtering) within autoclaved glass serum bottles under anoxic conditions at $30{ }^{\circ} \mathrm{C}$. To prepare starting cultures for experiments, the suspension was preserved by adding autoclaved glycerol (to a concentration of $15 \%$ )and dividing into autoclaved $2-\mathrm{mL}$ crimp-sealed vials for storage at $-80^{\circ} \mathrm{C}$.

To identify the time intervals for growth phases under operating conditions here, a vial of preserved S. barnesii cells were grown over two days as described above and sampled periodically for optical density by measuring light absorbance at $610 \mathrm{~nm}$ using a spectrophotometer (HACH DR 2700 spectrophotometer). FLogarithmic growth phase occurred between 10 and 30 hours, and stationary phase was identified after approximately 30 hours(Fig. S1 in the online supplement).Cells grown for all experiments were harvested in the stationary growth phase after approximately 36 hours unless otherwise noted. To correlate cell density and optical absorbance, cells were first harvested at stationary phase and enumerated by a DAPI(4',6-diamidino-2-phenylindole) staining method(Kepner Jr. \& Pratt, 1994)and a Zeiss Axio Imager M1 microscope. 
Systematic dilutions of the suspension with known cell concentration were measured spectrophotometrically at $610 \mathrm{~nm}$ and then used to create a standard curve for quantifying cell density within cell suspension experiments (Fig. S2 in the online supplement).

Cells for experimentation were grown in medium prepared in the anoxic chamber with autoclaved glassware. S. barnesiiSES-3 cells for experimentation were first grown by combining a vial of preserved cells and $0.5 \mathrm{~L}$ of fresh DSMZ growth medium 771 with lactate and nitrate. The suspension was divided into 250-ml autoclaved, crimpsealed serum bottles and incubated at $30{ }^{\circ} \mathrm{C}$ for 36 hours outside the anoxic chamber. The serum bottles were then returned to the anoxic chamber and verified for growth phase byoptical density measurements. Nitrate was chosen as the terminal electron acceptor for cell growth because cells grown with selenate as a terminal electron accepter, in otherwise identical medium,became encrusted with red $\mathrm{Se}^{0}$ precipitates and therefore became unsuitable for further cell suspension experiments.Furthermore, preliminary cell suspension experiments showed nitrate-grown cells reduced selenate more rapidly and to a greater extent than cells grown with selenate or fumarate (Fig. S3 in the online supplement).

To prepare cells for cell suspension experiments, grown cells were transferred to250-mlNalgene centrifuge bottles with O-ring sealing closures, tightly sealed, and centrifuged outside the chamber at $7900 \mathrm{xg}$ for 10 minutes. After being returned to the chamber, the medium was decanted, and the cells were rinsed and centrifuged again in a solution of Good's buffer (MES for $\mathrm{pH}$ 6.0, MOPS for $\mathrm{pH} 7.0$, and TAPS $\mathrm{pH} 8.0$ and 9.0, all at buffer concentrations of $20 \mathrm{mM}$ with $60 \mathrm{mM} \mathrm{NaCl}$ background electrolyte). 


\subsection{Cell suspension experiments}

Rinsed cells were re-suspended in $270 \mathrm{~mL}$ buffer solution and homogenized by magnetic stirring. Initial cell density was measured spectrophotometrically. Predetermined volumes of 1.6 M lactate stock solution, $400 \mathrm{mM}$ selenate stock solution, and buffer solution were then added to the cell suspension for a total volume of $300 \mathrm{~mL}$ to initiate reduction of selenate by $S$. barnesii SES-3. The suspension was immediately divided up into six 50-mL falcon tubes, and five of the tubes were placed on a rotator disc that agitated cell suspensions end-over-end inside the anoxic chamber (average temperature $24.6^{\circ} \mathrm{C}$ ). The remaining tube was immediately processed as an initial sample, and the remaining agitated tubes were sacrificed at approximately $0.5,1.5,5,10$, and 24 hours. Sacrificial tubes were used instead of operating one stirred batch reactor both to facilitate sample processing (which included centrifuging) and to help ensure that a representative sample containing all solid and dissolved contents, namely the solid $\mathrm{Se}(0)$ produced, was taken at each time point. In some experiments duplicate sacrificial reactors were processed at each time point to verify that there was no meaningful difference between tubes under the same conditions.

At the selected time points, sacrificial tubes were first removed from the glove box and centrifuged at $7900 \times \mathrm{g}$ for 10 minutes to separate solid and dissolved phases. The supernatant was then immediately filtered using Millipore Swinnexpolypropylene syringe-filter housings with $0.45 \mu \mathrm{m}$ mixed cellulose membrane and divided up for measurements of dissolved selenate, selenite, lactate, and acetate concentrations and for selenate- $\delta^{18} \mathrm{O}$ processing. When necessary, the filtered supernatant was stored at $4{ }^{\circ} \mathrm{C}$ in 
clean $50-\mathrm{mL}$ falcon tubes to await processing for isotope analysis. The $\mathrm{pH}$ of these storedsamples was adjusted (when necessary) with $0.1 \mathrm{M} \mathrm{NaOH}$ to $\mathrm{pH}$ 7.0-8.0 to prevent $\mathrm{O}$ exchange between selenate and $\mathrm{H}_{2} \mathrm{O}$ which occurs at acidic $\mathrm{pH}(\mathrm{O}$ kumura \& Okazaki, 1973b; Kaneko \& Poulson, 2012).The solids collected after the samples were centrifuged, which includedremaining cells and any elemental Se produced, were preserved by addition of about $2 \mathrm{~mL}$ of $0.1 \mathrm{M} \mathrm{HCl}$ to halt any cellular activity and were stored at $4{ }^{\circ} \mathrm{C}$.

\subsection{Analytical methods}

Dissolved Se(VI) and Se(IV) concentrations were measured with a Dionex DX120 ion chromatograph with a DionexIonPac AS9-HC analytical column and a12 mM $\mathrm{Na}_{2} \mathrm{CO}_{3}$ eluent at $1.0 \mathrm{ml} \mathrm{min}{ }^{-1}$ flowrate.No sulfate anions were observed to be present in ion chromatographs of samples from cell suspensions.Dissolved lactate and acetate concentrations were quantified using an Agilent Technologies 1260 Infinity SeriesHPLC with a Hamilton PRP-X300 analytical column and a $0.5 \mathrm{mM} \mathrm{H}_{2} \mathrm{SO}_{4}$ eluent at $2 \mathrm{ml} \mathrm{min}{ }^{-1}$ flowrate and UV detection at $210 \mathrm{~nm}$. Elemental Se was quantified by a colorimetric method(Biswas et al., 2011).Briefly, the centrifuged solids containing cells andSe(0) were acidified with $2 \mathrm{ml}$ of $0.1 \mathrm{M} \mathrm{HCl}$ to halt cell activity, centrifuged, and washed with $1 \mathrm{M} \mathrm{NaCl}$. The remaining $\mathrm{Se}(0)$ was combined with a colorless solution of $1 \mathrm{M} \mathrm{Na}_{2} \mathrm{~S}$ that produced an orange-red color upon sulfidization of $\operatorname{Se}(0)$. A final centrifugation step removed any other solids before quantification at $500 \mathrm{~nm}$ on a spectrophotometer. No color development was observed with cell suspensions unexposed to selenate. All dissolved analyte concentrations were determined in single measurements, but some 
experiments were repeated ( $\mathrm{pH}$ variability experiments) to show reproducibility.The red $\mathrm{Se}(0)$ precipitates were also analyzed by X-ray diffraction (XRD, Rigaku) with $\mathrm{CuK} \alpha$ radiation.

$\delta^{18} \mathrm{O}$ measurements of selenate were performed after processing aqueous samples according to a barium selenate precipitation method(Larese-Casanova \& Blake, 2013).Any dissolved selenite, which can also precipitate with barium cations and interfere with $\mathrm{BaSeO}_{4}$ measurements, was first removed by precipitation as $\mathrm{Ce}_{2}\left(\mathrm{SeO}_{3}\right)_{3}$ (s) by addition of cerium(III) chloride solution (Xia, 2014). Excess $\mathrm{Ce}^{3+}$ cations were removed from solution by exchange with $\mathrm{Na}^{+}$using Amberlite cation exchange resin. Selenate was then precipitated as $\mathrm{BaSeO}_{4(\mathrm{~s})}$ in glass tubes by addition offiltered $1 \mathrm{M}$ $\mathrm{BaCl}_{2}$ solution to a final concentration of $40-60 \mathrm{mM} \mathrm{Ba}{ }^{2+}$. The barium selenate was collected, dried, and weighed to determine $\mathrm{SeO}_{4}$ recovery.Our procedures usually resulted in mass recovery of selenate as $96-100 \%$, as determined by comparing the $\mu$ moles of selenate in $\mathrm{BaSeO}_{4}$ and $\mu$ moles of selenate originally dissolved in filtered samples. The cerium selenite precipitation step did not adversely affect either selenate recovery or $\delta^{18} \mathrm{O}$ measurements(Schellenger et al., 2014).

Approximately $300 \mu \mathrm{g}$ of each $\mathrm{BaSeO}_{4}$ sample was placed in Costech pressed silver capsules in triplicate and pyrolyzed in a Thermothermochemolysis elemental analyzer (TC/EA) at reactor temperature $1450{ }^{\circ} \mathrm{C}$ and $\mathrm{GC}$ column temperature $95^{\circ} \mathrm{C}$ ) and the $\mathrm{O}$ isotope composition was measured in a Thermo Delta $\mathrm{V}$ mass spectrometer coupled via a Conflo IV interface at the Environmental Biogeochemistry Lab, University of Delaware. Samples were calibrated to the Vienna Standard Mean Ocean Water (VSMOW) scale using an in-house barium selenate standard of $-10.3 \%$ which had been 
standardized according to a prior procedure(Larese-Casanova \& Blake, 2013), an inhouse silver phosphate standard of $+10 \%$, and IAEA-601 benzoic acid with value $+23.3 \%$.. The Rayleigh model was used to relate the fraction of dissolved selenate remaining to the $\delta^{18} \mathrm{O}$ values measured:

$$
\ln \left[\frac{\delta^{18} O+1000}{\delta^{18} O_{o}+1000}\right]=\frac{\varepsilon_{o}}{1000} \ln \left(\frac{C}{C_{o}}\right)
$$

where $\delta^{18} O_{o}$ is the initial $\delta^{18} \mathrm{O}$-selenate value, $\delta^{18} O$ is the $\delta^{18} \mathrm{O}$-selenate value at subsequent sample time points, $C_{o}$ is the initial selenate concentration, $C$ is the selenate concentration at subsequent sample time points, and $\varepsilon_{o}$ is the ${ }^{18} \mathrm{O}$-selenate enrichment factor. Samples for $\delta^{18} \mathrm{O}$-selenate at each time point were measured in triplicate and averaged. The standard deviations acrossall time points were, on average, $0.21 \%$, and were typically between $0.1-0.3 \%$. Sodium selenate $\left(\mathrm{Na}_{2} \mathrm{SeO}_{4}\right)$ from Acros Organics $\left(\delta^{18} \mathrm{O}\right.$ $-8.3 \%$ ) was used in all experiments, and deionized water had a $\delta^{18} \mathrm{O}$ value of $-6 \%$.

\section{Results and Discussion}

\subsection{Selenate Reduction}

Suspensions of $S$. barnesii coupled the oxidation of lactate to acetate with the reduction of selenate to selenite and elemental Se across a variety of chemical conditions. Fig. 1 provides a representative kinetic time course of these measured analyte concentrations over 24 hours at $\mathrm{pH} 8.0$, a solution $\mathrm{pH}$ chosen close to $S$. barnesii optimal $\mathrm{pH}$ and representative of slightly alkaline surface waters. Lactate consumption and selenite production are concurrent, while the products acetate and $\operatorname{Se}(0)$ appear only at 
later time points. Red $\mathrm{Se}(0)$ was apparent after a few hours, and this product was identified as trigonalSe by XRD (Fig. S4in the online supplement), identical to the Se allotrope observed during selenate reduction by green rust (Schellenger \& LareseCasanova, 2013) but different than the monoclinic Se allotrope previously observed to form by S. barnesii(Oremland et al., 2004). Control reactors containing cell suspensions with either only selenate or only lactate showed no loss of selenate or lactate, respectively, as well as no production of selenite, $\mathrm{Se}(0)$, or acetate (Fig. S5 in the online supplement). These observations verified the need for an external carbon and energy source for any selenate reduction, and they also confirm that the $\mathrm{H}_{2}$ present in the anoxic chamber atmosphere was not utilized as an energy source alone as already observed in previous studies (Stolz \& Oremland, 1999).Enzymatic reduction of selenate by washed $S$. barnesii cells grown with nitrate as a terminal electron acceptor here is consistent with prior studies that have reported selenate reduction as influenced by nitrate(Oremland et al., 1999)or have examined membrane-bound cytochrome activity(Stolz et al., 1997).

The Se mass balance remained steady and close to $100 \%$ over the course of the reaction, confirming that all Se species were accounted for and no loss of Se to tube surfaces or to headspace occurred. The amount of acetate produced after 24 hours (8.5 $\mathrm{mM})$ reasonably balanced the amount of lactate consumed $(10.31 \mathrm{mM})$. This equivalency of lactate consumption and acetate production is consistent with the general stoichiometric relationship of lactate oxidation coupled to selenate reduction in the following four-electron transfer reaction(Oremland et al., 1994):

$$
\text { Lactate }^{-}+2 \mathrm{SeO}_{4}^{2-} \rightarrow \text { Acetate }^{-}+2 \mathrm{SeO}_{3}^{2-}+\mathrm{HCO}^{3-}+\mathrm{H}^{+}
$$

as well as for selenite reduction by lactate: 
Lactate $^{-}+\mathrm{SeO}_{3}^{2-}+\mathrm{H}^{+} \rightarrow$ Acetate $^{-}+\mathrm{Se}(0)+\mathrm{HCO}_{3}{ }^{-}+\mathrm{H}_{2} \mathrm{O}$

(equation 3)

Selenate reduction may also be coupled to dissolved hydrogen oxidation when acetate is present as a carbon source(Stolz \& Oremland, 1999)and because $\sim 1 \% \mathrm{H}_{2}$ was present in the anoxic chamber atmosphere, this reaction may have occurred once acetate accumulated towards the end of the time course. Reduction of selenate directly to $\operatorname{Se}(0)$ seems unlikely considering the selenite buildup as an intermediate and the proposed separate enzyme requirements(Oremland et al., 1994). Bicarbonate measurements were not attempted, although $\mathrm{CO}_{2(\mathrm{~g})}$ has been confirmed by radiolabeled tracing as an oxidation product by others(Oremland et al., 1994). There was no evidence in HPLC chromatograms for lactate oxidation to pyruvate instead of acetate, previously observed with $S$. barnesii in high selenite concentrations and thought to be caused by inhibition of pyruvate dehydrogenase due to selenite toxicity(Oremland et al., 1994).

\section{2. ${ }^{18}$ O-Selenate Enrichment Values}

Selenate reduction by S. barnesii also caused a concurrent enrichment in ${ }^{18} \mathrm{O}$ isotopes of selenate still remaining within the dissolved, unreacted pool of selenate (Fig. 1b). Enrichment in selenate- ${ }^{18} \mathrm{O}$ is caused by a normal kinetic isotope effect in which the lighter ${ }^{16} \mathrm{O}$ isotopes are preferentially removed during the Se-O bond breaking process from $\mathrm{SeO}_{4}{ }^{2-}$ to $\mathrm{HSeO}_{3}{ }^{-}$. In fact, the kinetic evolution of $\delta^{18} \mathrm{O}$-selenate values followed selenate removal for all suspension conditions in which selenate reduction occurs (Fig. S6-S12 in the online supplement provides kinetic profiles). No significant change in $\delta^{18} \mathrm{O}$-selenate was observed in control experiments (Fig. S5 in the online supplement).Selenate reduction was tracked for suspensions across various geochemical 
conditions in order to establish how water chemistry may influence selenate reduction rates and ${ }^{18} \mathrm{O}$-selenate enrichment by $S$. barnesii. Others have reported strong links between cell-specific sulfate reduction rates and S fractionation (Kaplan \& Rittenberg, 1964), so water chemistries involving different cell densities, $\mathrm{pH}$, and substrate and terminal electron acceptor concentrations were varied here. The initial conditions for all cell suspension experiments are listed in Table 1.The Rayleigh fractionation model (equation 1) described well the ${ }^{18} \mathrm{O}$ enrichment in the dissolved, unreacted selenate pool (Fig.2a-c) and provided ${ }^{18} \mathrm{O}$ enrichment factors $\left(\varepsilon_{0}\right)$. The $\varepsilon_{\mathrm{o}}$ values across various suspension conditions for selenate reduction by S. barnesii all fall within a narrow range of $1.6-5.8 \%$ owith most measured standard deviations $<1.0 \%$ (Table 1 ). The upper value (5.8\%,suspension "CD 2.6" in Table 1, with $\mathrm{pH} 8.0$ and the highest cell density and highest lactate concentration) and lower value (1.6\%, suspension "pH7 A" in Table 1, with $\mathrm{pH} 7.0$ ) of $\varepsilon_{0}$ are statistically different from each other at the $95 \%$ confidence level, so the range is not attributed to solely random influences during analysis, but rather there may be some geochemical condition that favors somewhat higher or lower enrichment values.

For all suspension conditions, all ${ }^{18} \mathrm{O}$ measurements consistently followed fractionation theory throughout the entire time course without significant deviation from linearity $\left(R^{2}=0.80-1.00\right)$. This suggests that selenate reduction and ${ }^{18} \mathrm{O}$ enrichment was not perturbed during the time course and biochemical processes remained fairly consistent. The constant linear behavior according to the Rayleigh fractionation model has been reported for heavy Se isotopes for selenate during reduction with sulfate green rust (an $\mathrm{Fe}$ (II)-bearing layered double hydroxide mineral with intercalated sulfate anions) 
(Johnson \& Bullen, 2003), and with microbial consortia in natural sediment slurries (Ellis et al., 2003). However, deviations from linear enrichment has been reported during growth conditions with $S$. barnesii, with greater ${ }^{80} \mathrm{Se}$ enrichment observed at later growth stages, which was attributed to a slowing of the reduction step due to lack of nutrients or to possible toxicity from selenite accumulation (Herbel et al., 2000). A markedly nonlinear ${ }^{18} \mathrm{O}$ enrichment in selenate was also observed with chloride green rust, in which diffusive uptake between the double hydroxide layers was significantly more rapid than reduction, causing a sequestration of selenate from the dissolved, unreacted selenate pool prior to reduction (Schellenger \& Larese-Casanova, 2013).

\subsection{Influence of pH on Selenate Reduction Kinetics and ${ }^{18}$ O-Enrichment}

Correlations were attempted between the $\varepsilon_{\mathrm{o}}$ values and measured suspension conditions in order to determine if any geochemical parameter (solution $\mathrm{pH}$, cell density, lactate:selenate ratios, and cell-specific rate coefficients) strongly influences isotopic enrichment. The cell-specific rate coefficients were calculated by normalizing kinetic rate coefficients to cell density $(k / C D)$. Kinetic rate coefficients were determined using the pseudo-first order kinetic model, where the rate of selenate disappearance is proportional to the selenate concentration: $\mathrm{d}[\mathrm{Se}] / \mathrm{dt}=k[\mathrm{Se}]$, with $[\mathrm{Se}]$ as the concentration of dissolved selenate $(\mathrm{mM})$ and $k\left(\mathrm{~d}^{-1}\right)$ as the pseudo first order rate coefficient. This model assumes the disappearance rate is controlled only by the selenate concentration for a given suspension condition and not strongly influenced by a diffusion limitation.Selenate reduction time courses and kinetic modeling for all suspension conditions are provided in Fig. 3. The pseudo-first order model fits all experimental data 
well, with fitting coefficients $\chi^{2}<8$ and most values between 1.0 and $5.0\left(\mathrm{R}^{2}\right.$ values obtained from linear fits of log-normalized data were typically greater than 0.98 but at times around 0.92). Deviations of experimental measurements from fitted models toward the end of reaction for some conditions is suggestive of some change in suspension conditions that limit selenate reduction, such as encrustation of cells by $\mathrm{Se}(0)$ precipitates or limited availability of lactate. The zeroth order rate law, which applies to strongly diffusion limited conditions, did not fit the experimental data.

Faster overall selenate reduction was observed at more basic $\mathrm{pH}$, with nearly identical kinetic profiles at $\mathrm{pH} 8.0$ and 9.0 (Fig. 3a). The largest cell-specific rate $k / C D$ occurred for the two suspensions at $\mathrm{pH} 8.0$ (Table 1), a value close to $\mathrm{pH} 7.5$, the optimal $\mathrm{pH}$ for S. barnesii growth (Stolz et al., 1999), as well as the $\mathrm{pH} 7.3$ reported for other cell suspension experiments for S. barnesii(Herbel et al., 2000; Oremland et al., 1994; Laverman et al., 1995). Additionally, the continued selenate reduction at more alkaline conditions here suggests the optimal growth conditions may not restrict selenate metabolism in some natural settings such as alkaline lakes or even biotechnological treatment applications. However, the upper $\mathrm{pH}$ limit of selenate- or nitrate-grown $S$. barnesii has not been reported to the best of our knowledge, and noting that growth of $S$. barnesii on arsenate is possible only at $\mathrm{pH}$ between 6.5 and 8.5 (Switzer Blum et al., 1998), its presence may be found in more circumneutral $\mathrm{pH}$ settings.

Despite exhibiting only a small range of values (Fig. 2a), $\varepsilon_{0}$ appeared to have some correlation with solution $\mathrm{pH}$. A small but noticeable increase in $\varepsilon_{\mathrm{o}}$ occurred with increasing solution $\mathrm{pH}$, and this pattern was observed in two separate sets of experiments (Fig. 4a). ${ }^{18} \mathrm{O}$ enrichment in selenate at higher $\mathrm{pH}$ might result from the reduction step 
becoming more selective for ${ }^{16} \mathrm{O}$, perhaps by a slower electron transport or a faster initial diffusion of selenate into the membrane. However there is no evidence of either process from other kinetic observations or thermodynamic predictions. There is no correlation between $\varepsilon_{0}$ and $k$ or $k / C D$ for these six suspensions (Table 1). $\varepsilon_{0}$ also does not correlate with calculated Gibb's free energy of reaction for selenate reduction to selenite (equation 2) at $\mathrm{pH} 7.0,8.0$, and 9.0 (calculations are presented in the online supplement). Sulfur isotope fractionation during microbial sulfate reduction does not provide further insight, as $\mathrm{S}$ enrichment was found to be insensitive to $\mathrm{pH}$ (Detmers et al., 2001). The slight increase in $\varepsilon_{0}$ here might be related to a selenite toxicity effect suspected as a reason for an increase in Se fractionation during periods of selenite intermediate buildup (Herbel et al., 2000). In our experiments, significantly more buildup of selenite was observed at $\mathrm{pH}$ 8 and 9 after 24 hours compared to at pH 7 (Fig. 4b). These observations highlight the need for a more detailed understanding of enzyme complexes, forward and backward fluxes, and overall respiration mechanisms in bacteria that influence environmental toxins including selenium, arsenic, and other oxyanions.

\subsection{Influence of Cell Density and Lactate:Selenate Ratios on Selenate Reduction Kinetics} and ${ }^{18}$ O-Enrichment

S. barnesii cell density was varied in order to determine the range of density values that resulted in an observable ${ }^{18} \mathrm{O}$ enrichment within 24 hours and leaving no less than $\sim 1 \mathrm{mM}$ dissolved, unreacted selenate, the lower limit of our $\mathrm{BaSeO}_{4}$ precipitation procedure for $\delta^{18} \mathrm{O}$-selenate measurement (Fig. 3b). Cell suspensions with cell number

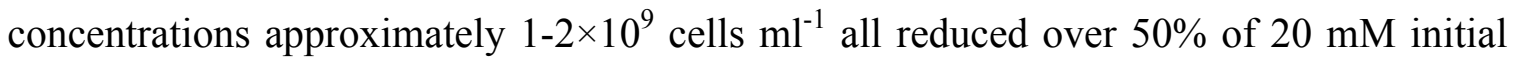


selenate at $\mathrm{pH}$ 8.0. Overall selenate reduction was faster with higher cell density, owing to a greater probability of selenate uptake by more cells. Pseudo-first order rate coefficients $k$ spanned a range of over one magnitude. $\mathrm{k} / C D$ values were calculated to check if the trend in overall selenate reduction rate can be explained only by cell density (Table 1). Indeed, cell specific rate coefficients were all close in value, within a factor of 2 , with only a slight increase in value with higher cell densities.

Because electron donor and electron acceptor concentrations have been reported to influence sulfate reduction rates and sulfur isotope fractionation (Canfield, 2001), experiments were conducted over a range of lactate:selenate ratios. Lactate and selenate concentrations were both varied to see if electron donor limiting conditions (lactate:selenate $<0.5$ ) would slow the reduction step. However, kinetic profiles normalized to initial selenate concentrations showed no substantial difference in the rate or extent of selenate reduction (Fig. 3c). The overall selenate rate coefficients and the cell specific rate coefficients were all close in value (Table 1). The smallest amount of lactate present in limiting amounts was still sufficient to sustain selenate reduction, and this rate invariability with electron donor availability points to the electron transfer step to selenate, and not the electron transfer step from lactate, as primarily rate limiting.

No relationship was found between $\varepsilon_{0}$ values and cell density, overall rate coefficients, cell specific rate coefficients, or lactate:selenate ratios. The lack of any trends is consistent with observations that Se isotope fractionation was invariant to maximum selenate reduction rates for two bacterial species during growth (Herbel et al., 2000), to temperature (Herbel et al., 2000), and to initial Se concentrations or solution chemistry by a native microbial consortia (Ellis et al., 2003). Work with sulfate reducing 
bacteria has shown that some electron donor limiting conditions result in larger fractionation of S in sulfate (Detmers et al., 2001; Brüchert et al., 2001); however this same trend was not observed with initial lactate concentrations here. Finally, there are mixed reports as to whether specific sulfate reduction rates influence $\mathrm{S}$ fractionation in sulfate; whether faster rates cause an S fractionation increase (Canfield et al., 2006), decrease (Kaplan \& Rittenberg, 1964; Habicht \& Canfield, 1997), or no change (Detmers et al., 2001; Bolliger et al., 2001). The cell specific rate coefficients $k / C D$ in our experiments, although spanning a narrow range of only a factor of five, do not correlate with $\varepsilon_{0}$. Expanding the range of $k / C D$ may reveal a wider range of $\varepsilon_{0}$ values, and this might be accomplished by providing different electron donor compounds (Kaplan \& Rittenberg, 1964; Detmers et al., 2001) or by examining bacteria species with different Se-metabolizing capabilities, such as Thanera selenatis, which reduces selenate with a different periplasmic selenate reductase enzyme (Lowe et al., 2010), or Pseudomonas stutzeri, which may reduce selenate but cannot grow with it as a terminal electron acceptor (Lortie et al., 1992).

\subsection{Relationship between $\varepsilon_{o}$ and Literature $\varepsilon_{S e}$ Values}

To best describe the relationship between our measured $\varepsilon_{0}$ values and the $\varepsilon_{\mathrm{Se}}$ values reported in the literature for both biotic and abiotic processes, the mult-step model for isotopic enrichment must first be invoked. The kinetic isotope effect observed during microbial metabolism has been conceptually modeled as a two-step process involving diffusion to the reactive site followed by reduction, first proposed for sulfate reduction (Rees, 1973) and later adopted to support selenate reduction (Johnson, 2004; Herbel et 
al., 2000). In order for the reactive enzyme site to have time to be selective for selenate with the lighter isotopes, the reduction step must he slower than the forward diffusion step that delivers selenate molecules (of various isotopic combinations) to the cytochrome. Moreover, in order for selenate with heavier isotopes to be observed within the bulk- dissolved pool, some backwards diffusion of unreacted, heavier selenate from the reactive cytochrome site is required (Johnson, 2004). Therefore, our observation of stable oxygen isotope enrichment supports the notion that electron transfer is the ratelimiting step or at least partly rate-limiting during the dissimilatory selenate reduction process (Johnson, 2004; Ellis et al., 2003; Herbel et al., 2000). Kaplan and Rittenberg (1964) argued that, for sulfate reduction with organic substrates as electron donors, diffusion of sulfate into the cell should be nearly fractionless, and reduction should be the fractionating, rate-limiting step.

However, the possibility of diffusion limitations on $\varepsilon_{0}$ values is needed to explain the difference between ${ }^{18} \mathrm{O}$ enrichment for biotic and abiotic processes. $\varepsilon_{0}$ values from biotic reduction by $S$. barnesii here (1.6-5.8\%) are significantly less than $\varepsilon_{0}$ values observed for abiotic reduction with Fe(II)-rich minerals chloride green rust and ferrous hydroxide ( 20\%) (Schellenger \& Larese-Casanova, 2013). When the diffusion rate is much faster than the reduction rate, reduction is the rate-limiting step, and the electron transfer mechanism has time to select for selenate with the preferred lighter Se and O isotopes, resulting in large enrichment values. This case best describes the large $\varepsilon_{0}$ observed for selenate reaction with chloride green rust that involved a rapid uptake step followed by a slower electron transfer step from Fe(II) to selenate. However, when diffusion rate slows to be closer to reduction rate, both steps may be partly rate-limiting, 
and reduction occurs shortly after forward diffusion with less time to select for selenate with lighter isotopes, resulting in smaller enrichment values. Moreover, a slower backwards diffusion may also limit re-equilibration of isotopically heavy selenate with the bulk dissolved pool. This case likely describes the smaller $\varepsilon_{0}$ observed with $S$. barnesii, in which diffusion onto, into, or through cell membranes may induce a mass transfer limitation.

Although the ${ }^{18} \mathrm{O}$-enrichment in abiotic reduction is greater than that for $\mathrm{Se}$ (a difference anticipated by the differences in relative mass of the isotopes), this did not hold true for biotic reduction in our case. $\varepsilon_{0}$ values for $S$. barnesii are presently in the same range of $\varepsilon_{\mathrm{Se}}$ values reported for $S$. barnesii and B. arsenicoselenatis for selenate reduction in pure cultures(Herbel et al., 2000). Unlike chemical reduction with green rusts, fractionation in $\mathrm{O}$ might not be more sensitive than fractionation in Se during biological reduction. The lack of element-specific fractionation here in biological reduction in contrast to mineralogical reduction might also result from the enzymatic reduction process in $S$. barnesii being more complex and possibly having unknown reactions influencing $\mathrm{O}$ isotopic content. For one, the pathways and enzymes have not been fully elucidated for S. barnesii(Stolz et al., 1997), and it could be speculated that reverse redox reactions occur, such as re-oxidation of formed selenite to selenate, that alter oxygen isotopic ratios. In microbial sulfate reduction, intracellularly-formed sulfite was found to equilibrate $\mathrm{O}$ with $\mathrm{H}_{2} \mathrm{O}$, re-oxidize to sulfate, and partially overwrite ${ }^{18} \mathrm{O}$ fractionation caused by sulfate reduction(Mangalo et al., 2007).Moreover, there is some evidence that oxyanions can have variable relative enrichments in their $\mathrm{O}$ and central atom. The relative fractionation of $\mathrm{O}$ and $\mathrm{N}$ during microbial nitrate reduction has been 
reported to vary widelywith $\varepsilon_{0}: \varepsilon_{\mathrm{N}}$ ratios between $0.5-1.0$ depending on geochemical conditions and microbial species (Granger et al., 2008; Wunderlich et al., 2012), and slower net sulfate reduction rates were found to lead to improved ${ }^{18} \mathrm{O}$ enrichment compared to ${ }^{34} \mathrm{~S}$ enrichment in marine settings (Antler et al., 2013). Lastly, the similar values of biotic $\varepsilon_{0}\left(\sim 1-5 \%\right.$ ) (this study), biotic $\varepsilon_{\mathrm{Se}}(\sim 1-9 \%$ ) (Herbel et al., 2000), and abiotic $\varepsilon_{\mathrm{Se}}(\sim 7 \%)$ (Johnson \& Bullen, 2003) could be explained by these three measurements occurring under similar mass transfer limitations, whereas abiotic $\varepsilon_{0}$ $(\sim 20 \%$ ) (Schellenger \& Larese-Casanova, 2013) was not limited in this way. Compared to rapid selenate uptake ( $<5 \mathrm{~min})$ by chloride green rust, $\varepsilon_{\mathrm{Se}}$ measured with sulfate green rust may be artificially low due to slower selenate interlayer uptake caused by the green rust's stronger affinity for sulfate over selenate (Miyata, 1983). The influence of mass transfer onto $\mathrm{O}$ and $\mathrm{Se}$ enrichment during environmentally-relevant selenate reduction processes could be more definitively established by simultaneously measuring $\mathrm{O}$ and $\mathrm{Se}$ fractionation under various mass transfer limited conditions, such as with green rusts with different exchange preferences, with bacteria possessing different Se metabolic pathways, or with purely dissolved chemical solutions.

Finally, the ${ }^{18} \mathrm{O}$ enrichment observed during microbial selenate reduction is consistent with the normal kinetic isotope effects observed for ${ }^{18} \mathrm{O}$ during microbial reduction of sulfate, nitrate, and perchlorate, and during chemical reduction of nitrite (with $\mathrm{Fe}(\mathrm{II})$ ). However, the enrichment factors $\varepsilon_{\mathrm{o}}$ for selenate (1.6-5.8 \%o) are generally less than biotic $\varepsilon_{0}$ for nitrate (4.2-20\%) (Wunderlich et al., 2012; Knöller et al., 2011), biotic $\varepsilon_{0}$ for perchlorate (29.9-36.6\%) (Sturchio et al., 2007), and abiotic $\varepsilon_{0}$ for nitrite (9.8\%)(Jones et al., 2015). $\quad \varepsilon_{0}$ values as determined by Rayleigh fractionation for biotic 
sulfate reduction and nitrite reduction are not available, to the best of our knowledge, due to the fast equilibration of $\mathrm{O}$ with $\mathrm{H}_{2} \mathrm{O}$ for the intermediate sulfite and the parent nitrite, respectively(Brunner et al., 2005; Casciotti et al., 2007). The enzymatic pathways and Se and $\mathrm{O}$ fractionations at each step should be explored in similar detail as in sulfate and nitrate reduction to best understand the apparently smaller ${ }^{18} \mathrm{O}$ fractionation observed for selenate relative to other oxyanions.

\subsection{Environmental Implications}

${ }^{18} \mathrm{O}$ enrichment of selenate provides a useful second means to isotopically characterize Se oxyanions within surface, subsurface, or wetland waters.Stable oxygen isotopes, like those of Se, may not be preserved in chemically reducing environments, and changes in their $\delta^{18} \mathrm{O}$ values, when observable, may be indicative of recent selenate reduction occurrence. Distinction between abiotic and biotic selenate reduction might be possible so long as a large difference in ${ }^{18} \mathrm{O}$-selenate enrichments observed within laboratory experiments generally holds true for natural conditions. Fig. 5 illustrates that biotic $\varepsilon_{0}$ values may occupy a range of values far less than abiotic $\varepsilon_{0} .{ }^{18} \mathrm{O}$ enrichment caused by sorption processes, such as that observed for selenate uptake by iowaite, is small but close to the low end of biotic $\varepsilon_{0}$ values, and this overlap may lead to misinterpretation of field observations when both sorption and microbial reduction are important(Ellis et al., 2003). A dual Se and O isotope approach, similar to those used for elements within organic compounds (Audí-Miró et al., 2013; Hofstetter et al., 2011), may be useful for characterizing Se pollution within sites exhibiting plume-type 
behavior(Bailey et al., 2015) or sites with active Se bioremediation (Williams et al., 2013).Reduction might imprint $\mathrm{O}$ enrichment more noticeably than Se in selenate due to its greater mass difference among isotopes. With greater enrichment so far observed in $\mathrm{O}$ by green rust reduction of selenate, field sites where mineralogical reduction dominates, such as anoxic, Fe(II)-rich sediments or even Fe-amended groundwater, may be the most promising for observing large ${ }^{18} \mathrm{O}$-selenate fractionation.

While trends observed in laboratory experiments might be helpful for interpreting field observations, enrichment values typically do not directly translate to nature. Whether enrichments observed in laboratory pure cultures are relevant to natural settings requires additional considerations on the physical and biogeochemical nature of the setting. Variability in microbial consortia, carbon substrate type and abundance, nutrient availability, and diffusion could cause significant deviation from laboratory observations and across sites(Johnson, 2004). Se fractionation has been shown to be diminished due to pore diffusion restrictions in which enriched selenate may not easily transport back to bulk water phase(Clark \& Johnson, 2008). Relatedly, field observations at an active Se reducing site found Se fractionation much smaller than expected and consequently not effective for process identification(Clark \& Johnson, 2010). If diffusion restrictions also affect ${ }^{18} \mathrm{O}$ fractionation, $\delta^{18} \mathrm{O}$-selenate values in the field may be well less than the $\sim 6 \%$ values observed in the laboratory. Similar to the low Se isotope fractionation observed in those studies, $\varepsilon_{O}$ values in the field may be less than $1 \%$.

Measurements of $\delta^{18} \mathrm{O}$ in selenate from natural water samples are yet to be performed due to some challenges in sample preparation. For one, selenate concentrations in nature are typically $1 \mu \mathrm{M}$ or less(Seiler et al., 1999), so concentration 
steps with anion exchange media would be required to reach the $\sim 1 \mathrm{mM}$ amount currently used for $\mathrm{BaSeO}_{4(\mathrm{~s})}$ formation and recovery, or improved selenate precipitation methods are needed for lower Se concentrations. Selenate would need to be harvested from small volumes of pore water where Se concentrations (and isotopic values) may vary over centimeter distances or less. Other inorganic oxyanions that are insoluble with $\mathrm{Ba}^{2+}$ must be removed prior to $\mathrm{Ba}^{2+}$ addition, and while selenite, carbonate, arsenate, and phosphate are easily removed by precipitation with $\mathrm{Ce}^{3+}(\mathrm{Xia}, 2014)$, a means to separate selenate from sulfate must be obtained. $\delta^{18} \mathrm{O}$-selenate quantification, when finalized for natural samples, could provide insight to selenate fate determination as well as source identification. Future studies should explore Se oxidation processes in the Se redox cycle

and how ${ }^{18} \mathrm{O}$ can trace the formation of selenate from selenite. Observing ${ }^{18} \mathrm{O}$ fractionation processes throughout the Se redox cycle could improve understanding of how Se oxyanions dissolve, mobilize, and immobilize within water resources.

\section{Conclusions}

This study reports the fractionation of ${ }^{18} \mathrm{O}$ in selenate during microbial selenate reduction to selenite by the dissimilatory Se-reducing bacterium S. barnesii SES-3. ${ }^{18} \mathrm{O}$ enrichment within the dissolved, unreacted selenate pool $\left(\varepsilon_{0}\right)$ could be modeled with Rayleigh fractionation theory and produced $\varepsilon_{O}$ values of $1.5-5.8 \%$. This study complements prior reports on fractionation of Se isotopes during biotic and abiotic reduction of selenate. The range of $\varepsilon_{O}$ values are similar to the reported range of $\varepsilon_{\mathrm{Se}}$ values for microbial reduction but far less than $\varepsilon_{O}$ values reported for mineralogical 
reduction. The diminished enrichment values in the biological laboratory experiments compared to reported mineralogical experiments are attributed to a masking effect by the diffusion of selenate into or out of the selenate-enzyme complex.However, $\varepsilon_{O}$ values were expected to be greater than reported $\varepsilon_{\mathrm{Se}}$ values due to the isotopic mass difference, but this was not observed. Because selenate, like sulfate, preserves its $\mathrm{O}$ isotopic values without exchanging them with $\mathrm{H}_{2} \mathrm{O}$ molecules under most environmental $\mathrm{pH}$ conditions,

${ }^{18} \mathrm{O}$ enrichment caused by microbial (or mineralogical) reduction in field sites may leave an imprint of active reducing zones. The combination of this work with the enrichment factors developed for Se allow for a dual isotope approach in identifying reduction reactions, and potentially in exploring mechanisms of reaction. Overall, microbial reduction of selenate contributes to oxygen isotope variability in selenate within natural settings. In order to illustrate a fuller picture of isotope systematics within Se redox cycling, future avenues of investigation should include oxygen isotope fractionation and incorporation during Se oxidation reactions.

\section{Acknowledgements}

We thank Sanjeev Mukerjee (Northeastern University) for assistance with XRD measurements.We also thank the anonymous reviewers whose comments greatly improved the manuscript. This work was supported by Northeastern University and the National Science Foundation (grant $\mathrm{CBET}^{7}$ 1236182). 


\section{Appendix A. Supplementary material}

The Appendix contains graphical information for measurements made in all cell suspension experiments, thermodynamic calculations, and one x-ray diffraction pattern. Supplementary data associated with this article can be found in the online version. 


\section{References}

Antler, G., Turchyn, A.V., Rennie, V., Herut, B., Sivan, O., 2013. Coupled sulfur and oxygen isotope insight into bacterial sulfate reduction in the natural environment. Geochim. Cosmochim. Acta 118, 98-117.

Audí-Miró, C., Cretnik, S., Otero, N., Palau, J., Shouakar-Stash, O., Soler, A., Elsner, M., 2013. $\mathrm{Cl}$ and $\mathrm{C}$ isotope analysis to assess the effectiveness of chlorinated ethene degradation by zero-valent iron: Evidence from dual element and product isotope values. Appl. Geochem. 32, 175-183.

Bailey, R.T., Romero, E.C., Gates, T.K., 2015. Assessing best management practices for remediation of selenium loading in groundwater to streams in an irrigated region. J. Hydrol. 521, 341-359.

Biswas, K.C., Barton, L.L., Tsui, W.L., Shuman, K., Gillespie, J., Eze, C.S., 2011. A novel method for the measurement of elemental selenium produced by bacterial reduction of selenite. J. Microbiol. Methods 86, 140-144.

Blake, R.E., O’Neil, J.R., Surkov A., 2005. Biogeochemicalcycling of phosphorus:insights from oxygen isotope effects ofphosphoenzymes. Am. J. Sci. 305, $596-620$.

Bolliger, C., Schroth, M.H., Bernasconi, S.M., Kleikemper, J., Zeyer, J., 2001. Sulfur isotope fractionation during microbial sulfate reduction by toluene-degrading bacteria. Geochim. Cosmochim. Acta 65, 3289-3298. 
Brüchert, V., Knoblauch, C., Jørgensen, B.B., 2001. Controls on stable sulfur isotope fractionation during bacterial sulfate reduction in Arctic sediments. Geochim.

Cosmochim. Acta 65, 763-776.

Brunner, B., Bernasconi, S.M., Kleikemper, J., Schroth, M.H., 2005. A model for oxygen and sulfur isotope fractionation in sulfate during bacterial sulfate reduction processes. Geochim. Cosmochim. Acta 69, 4773-4785.

Canfield, D.E., 2001. Isotope fractionation by natural populations of sulfate-reducing bacteria. Geochim. Cosmochim. Acta 65, 1117-1124.

Canfield, D.E., Olesen, C.A., Cox, R.P., 2006. Temperature and its control of isotope fractionation by a sulfate-reducing bacterium. Geochim. Cosmochim. Acta 70, 548-561.

Casciotti, K.L., Böhlke, J.K., McIlvin, M.R., Mroczkowski, S.J., Hannon, J.E., 2007. Oxygen isotopes in nitrite: Analysis, calibration, and qquilibration. Anal. Chem. 79, $2427-2436$.

Christiansen, B.C., Balic-Zunic, T., Dideriksen, K., Stipp, S.L.S., 2009. Identification of green rust in groundwater. Environ. Sci. Technol. 43, 3436-3441.

Clark, S.K., Johnson, T.M., 2010. Selenium stable isotope investigation into selenium biogeochemical cycling in a lacustrine environment: Sweitzer Lake, Colorado. J. Environ. Qual. 39, 2200-2210. 
Clark, S.K., Johnson, T.M., 2008. Effective isotopic fractionation factors for solute removal by reactive sediments: A laboratory microcosm and slurry study. Environ. Sci. Technol. 42, 7850-7855.

DeMoll-Decker, H., Macy, J.M., 1993. The periplasmic nitrite reductase of Thauera selenatis may catalyze the reduction of selenite to elemental selenium. Arch. Microbiol. $160,241-247$.

Detmers, J., Bruchert, V., Habicht, K.S., Kuever, J., 2001. Diversity of sulfur isotope fractionations by sulfate-reducing prokaryotes. Appl. Environ. Microbiol. 67, 888-894.

Ellis, A.S., Johnson, T.M., Herbel, M.J., Bullen, T.D., 2003. Stable isotope fractionation of selenium by natural microbial consortia. Chem. Geol. 195, 119-129.

Fan, T.W.-., Higashi, R.M., Lane, A.N., 1998. Biotransformations of selenium oxyanion by filamentous cyanophyte-dominated mat cultured from agricultural drainage waters. Environ. Sci. Technol. 32, 3185-3193.

Frankenberger, W.T.J., Arshad, M., 2001. Bioremediation of selenium-contaminated sediments and water. BioFactors 14, 241-254.

Granger, J., Sigman, D.M., Lehmann, M.F., Tortell, P.D., 2008. Nitrogen and oxygen isotope fractionation during dissimilatory nitrate reduction by denitrifying bacteria. Limnol. Oceanogr. 53, 2533-2545.

Habicht, K.S., Canfield, D.E., 1997. Sulfur isotope fractionation during bacterial sulfate reduction in organic-rich sediments. Geochim. Cosmochim. Acta 61, 5351-5361. 
Harrison, A.G., Thode, H.G., 1958. Mechanism of the bacterial reduction of sulphate from isotope fractionation studies. Trans Faraday Soc. 54, 84-96.

Herbel, M.J., Johnson, T.M., Oremland, R.S., Bullen, T.D., 2000. Fractionation of selenium isotopes during bacterial respiratory reduction of selenium oxyanions. Geochim. Cosmochim. Acta 64, 3701-3709.

Hofstetter, T.B., Bolotin, J., Skarpeli-Liati, M., Wijker, R., Kurt, Z., Nishino, S.F., Spain, J.C., 2011. Tracking transformation processes of organic micropollutants in aquatic environments using multi-element isotope fractionation analysis. Appl. Geochem. 26, Supplement, S334-S336.

Johnson, T.M., 2004. A review of mass-dependent fractionation of selenium isotopes and implications for other heavy stable isotopes. Chem. Geol. 204, 201-214.

Johnson, T.M., Bullen, T.D., 2003. Selenium isotope fractionation during reduction by Fe(II)-Fe(III) hydroxide-sulfate (green rust). Geochim. Cosmochim. Acta 67, 413-419.

Jones, L.C., Peters, B., Lezama Pacheco, J.S., Casciotti, K.L., Fendorf, S., 2015. Stable isotopes and iron oxide mineral products as markers of chemodenitrification. Environ. Sci. Technol. 49, 3444-3452.

Kaneko, M., Poulson, S.R., 2012. Rate of oxygen isotope exchange between selenate and water. Environ. Sci. Technol. 46, 4539-4545.

Kaplan, I.R., Rittenberg, S.C., 1964. Microbial fractionation of sulphur isotopes. J. Gen. Microbiol. 34, 195-212. 
Kendall, C., 1998. Tracing nitrogen sources and cycles in catchments. In: Isotope tracers in catchment hydrology. Kendall C, McDonnell JJ(eds). Elsevier Science, Amsterdam, pp $519-576$.

Kepner Jr., R.L., Pratt, J.R., 1994. Use of fluorochromes for direct enumeration of total bacteria in environmental samples: Past and present. Microbiol. Rev. 58, 603-615.

Knöller, K., Vogt, C., Haupt, M., Feisthauer, S., Richnow, H., 2011. Experimental investigation of nitrogen and oxygen isotope fractionation in nitrate and nitrite during denitrification. Biogeochemistry 103, 371-384.

Larese-Casanova, P., Blake, R.E., 2013. Measurement of $\delta^{18} \mathrm{O}$ values in arsenic and selenium oxyanions. Rapid Commun. Mass Spectrom. 27, 117-126.

Laverman, A., Blum, J., Schaefer, J., Phillips, E., Lovley, D., Oremland, R., 1995. Growth of strain SES-3 with arsenate and other diverse electron acceptors. Appl. Environ. Microbiol. 61, 3556-3561.

Lemly, A.D., 2004. Aquatic selenium pollution is a global environmental safety issue. Ecotoxicol. Environ. Saf. 59, 44-56.

Lemly, A.D., 2002. Symptoms and implications of selenium toxicity in fish: the Belews Lake case example. Aquat. Toxicol. 57, 39-49.

Lemly, A.D., 1985. Toxicology of selenium in a freshwater reservoir: Implications for environmental hazard evaluation and safety. Ecotoxicol. Environ. Saf. 10, 314-338. 
Liang, X., Dong, Y., Kuder, T., Krumholz, L.R., Philp, R.P., Butler, E.C., 2007.

Distinguishing abiotic and biotic transformation of tetrachloroethylene and trichloroethylene by stable carbon isotope fractionation. Environ. Sci. Technol. 41, 70947100.

Lortie, L., Gould, W.D., Rajan, S., McCready, R.G.L., Cheng, K.-J., 1992. Reduction of selenate and selenite to elemental selenium by a Pseudomonas stutzeri isolate. Appl. Environ. Microbiol. 58, 4042-4044.

Lowe, E.C., Bydder, S., Hartshorne, R.S., Tape, H.L.U., Dridge, E.J., Debieux, C.M., Paszkiewicz, K., Singleton, I., Lewis, R.J., Santini, J.M., Richardson, D.J., Butler, C.S., 2010. Quinol-cytochrome c oxidoreductase and cytochrome c4 mediate electron transfer during selenate respiration in Thauera selenatis. J. Biol. Chem. 285, 18433-18442.

Macy, J.M., Michel, T.A., Kirsch, D.G., 1989. Selenate reduction by a Pseudomonas species: a new mode of anaerobic respiration. FEMS Microbiol. Let. 61, 195-198.

Macy, J.M., Rech, S., Auling, G., Dorsch, M., Stackebrandt, E., Sly, L.I., 1993. Thauera selenatis gen. nov., sp. nov., a member of the beta subclass of Proteobacteria with a novel type of anaerobic respiration. Int. J. Syst. Bacteriol. 43, 135-142.

Maiers, D.T., Wichlacz, P.L., Thompson, D.L., Bruhn, D.F., 1988. Selenate reduction by bacteria from a selenium-rich environment. Appl. Environ. Microbiol. 54, 2591-2593.

Mangalo, M., Meckenstock, R.U., Stichler, W., Einsiedl, F., 2007. Stable isotope fractionation during bacterial sulfate reduction is controlled by reoxidation of intermediates. Geochim. Cosmochim. Acta 71, 4161-4171. 
Mast, M.A., Mills, T.J., Paschke, S.S., Keith, G., Linard, J.I., 2014. Mobilization of selenium from the Mancos Shale and associated soils in the lower Uncompahgre River Basin, Colorado. Appl. Geochem. 48, 16-27.

Miyata, S., 1983. Anion-exchange properties of hydrotalcite-like compounds. Clays and Clay Minerals 31, 305-311.

Myneni, S.C.B., Tokunaga, T.K., Brown, G.E., Jr., 1997. Abiotic selenium redox transformations in the presence of Fe(II,III) oxides. Science 278, 1106-1109.

Ohlendorf, H.M., Hoffma, D.J., Saiki, M.K., Aldrich, T.W., 1986. Embryonic mortality and abnormalities of aquatic birds: Apparent impacts of selenium from irrigation drainwater. Sci. Total Environ. 52, 49-63.

Okumura, A., Okazaki, N., 1973a. Kinetics of oxygen exchange between selenite ions and water. Bull. Chem. Soc. Jap. 46, 1084-1088.

Okumura, A., Okazaki, N., 1973b. Kinetics of oxygen exchange between selenate ions and water. Bull. Chem. Soc. Jap. 46, 1080-1084.

Oremland, R.S., Blum, J.S., Bindi, A.B., Dowdle, P.R., Herbel, M., Stolz, J.F., 1999. Simultaneous reduction of nitrate and selenate by cell suspensions of selenium-respiring bacteria. Appl. Environ. Microbiol. 65, 4385-4392.

Oremland, R.S., Blum, J.S., Culbertson, C.W., Visscher, P.T., Miller, L.G., Dowdle, P., Strohmaier, F.E., 1994. Isolation, growth, and metabolism of an obligately anaerobic, selenate-respiring bacterium, strain SES-3. Appl. Environ. Microbiol. 60, 3011-3019. 
Oremland, R.S., Herbel, M.J., Blum, J.S., Langley, S., Beveridge, T.J., Ajayan, P.M., Sutto, T., Ellis, A.V., Curran, S., 2004. Structural and spectral features of selenium nanospheres produced by Se-respiring bacteria. Appl. Environ. Microbiol. 70, 52-60.

Oremland, R.S., Hollibaugh, J.T., Maest, A.S., Presser, T.S., Miller, L.G., Culbertson, C.W., 1989. Selenate reduction to elemental selenium by anaerobic bacteria in sediments and culture: Biogeochemical significance of a novel, sulfate-independent respiration. Appl. Environ. Microbiol. 55, 2333-2343.

Presser, T.S., 1994. The Kestersen effect. Environ. Manage. 18, 437-454.

Rees, C.B., 1973. A steady-state model for sulphur isotope fractionation in bacterial reduction processes. Geochim. Cosmochim. Acta 37, 1141-1162.

Schellenger, A.E.P., Larese-Casanova, P., 2013. Oxygen isotope indicators of selenate reaction with Fe(II) and Fe(III) hydroxides. Environ. Sci. Technol. 47, 6254-6262.

Schellenger, A.E.P., Xia, L., Jaisi, D., Onnis-Hayden, A., Larese-Casanova, P., 2014. Stable oxygen isotope enrichment during biotic and abiotic reduction of selenate. $249^{\text {th }}$ National Meeting, American Chemical Society, Denver, CO, United States, March 22-26, 2015. .

Schilling, K., Johnson, T.M., Wilcke, W., 2013. Isotope fractionation of selenium by biomethylation in microcosm incubations of soil. Chem. Geol. 352, 101-107.

Schilling, K., Johnson, T.M., Wilcke, W., 2011a. Selenium partitioning and stableisotope ratios in urban topsoils. Soil Sci. Soc. Am. J. 75, 1354-1364. 
Schilling, K., Johnson, T.M., Wilcke, W., 2011b. Isotope fractionation of selenium during fungal biomethylation by Alternaria alternata. Environ. Sci. Technol. 45, 26702676.

Seiler, R.L., Skorupa, J.P., Peltz, L.A., 1999. Areas susceptible to irrigation-induced selenium contamination of water and biota in the western United States. USGS Circular 1180, 1-36.

Stolz, J.F., Oremland, R.S., 1999. Bacterial respiration of arsenic and selenium. FEMS Microbiol. Rev. 23, 615-627.

Stolz, J.F., Gugliuzza, T., Blum, J.S., Oremland, R., Murillo, F.M., 1997. Differential cytochrome content and reductase activity in Geospirillum barnesii strain SeS3. Arch. Microbiol. 167, 1-5.

Stolz, J.F., Ellis, D.J., Blum, J.S., Ahmann, D., Lovley, D.R., Oremland, R.S., 1999. Sulfurospirillum barnesii sp. nov. and Sulfurospirillum arsenophilum sp. nov., new members of the Sulfurospirillum clade of the $\varepsilon$ Proteobacteria. Int. J. Syst. Bacteriol. 49, $1177-1180$.

Sturchio, N.C., Bohlke, J.K., Beloso, A.D.J., Streger, S.H., Heraty, L.J., Hatzinger, P.B., 2007. Oxygen and chlorine isotopic fractionation during perchlorate biodegradation: Laboratory results and implications for forensics and natural attenuation studies. Environ. Sci. Technol. 41, 2796-2802.

Switzer Blum, J., Bindi, A.B., Buzzelli, J., Stolz, J.F., Oremland, R.S., 1998. Bacillus arsenicoselenatis, sp. nov., and Bacillus selenitireducens, sp. nov.: two haloalkaliphiles 
from Mono Lake, California that respire oxyanions of selenium and arsenic. Arch. Microbiol. 171, 19-30.

Switzer Blum, J., Stolz, J.F., Oren, A., Oremland, R.S., 2001. Selenihalanaerobacter shriftii gen nov., sp. nov., a halophilic anaerobe from Dead Sea sediments that respires selenate. Arch. Microbiol. 175, 208-219.

Turchyn, A.V., Volker, B., Lyons, T.W., Engel, G.S., Balci, N., Schrag, D.P., Brunner, B., 2010. Kinetic oxygen isotope effects during dissimilatorysulfate reduction: a combined theoretical and experimental approach.Geochim. Cosmochim. Acta 74, 20112024.

Tuttle, M.L.W., Fahy, J.W., Elliott, J.G., Grauch, R.I., Stillings, L.L., 2014.

Contaminants from Cretaceous black shale: I. Natural weathering processes controlling contaminant cycling in Mancos Shale, southwestern United States, with emphasis on salinity and selenium. Appl. Geochem. 46, 57-71.

Williams, K.H., Wilkins, M.J., N'Guessan, A.L., Arey, B., Dodova, E., Dohnalkova, A., Holmes, D., Lovley, D.R., Long, P.E., 2013. Field evidence of selenium bioreduction in a uranium-contaminated aquifer. Environ. Microbiol. Rep. 5, 444-452.

Wunderlich, A., Meckenstock, R., Einsiedl, F., 2012. Effect of different carbon substrates on nitrate stable isotope fractionation during microbial denitrification. Environ. Sci. Technol. 46, 4861-4868.

Lichao Xia. 2014. Isolation of selenate oxyanions and characterization of selenate $\delta^{18} \mathrm{O}$ from diverse aqueous solutions. Masters Thesis, Northeastern University. 
Table 1: Summary of cell suspension conditions, observed ${ }^{18} \mathrm{O}$-selenate enrichment values, and modeled first-order rate coefficients.

\begin{tabular}{|c|c|c|c|c|c|c|c|c|c|}
\hline \multirow[t]{2}{*}{$\begin{array}{c}\text { Experiment } \\
\text { Label }\end{array}$} & \multirow[t]{2}{*}{ pH } & $\begin{array}{c}\text { Cell } \\
\text { Density }\end{array}$ & $\begin{array}{c}\text { Initial } \\
{\left[\mathrm{SeO}_{4}{ }^{2-}\right.} \\
\quad]\end{array}$ & $\begin{array}{c}\text { Initial } \\
\text { [Lactate] }\end{array}$ & $\begin{array}{l}\text { Lact./ } \\
\mathrm{SeO}_{4} \\
\text { Ratio }\end{array}$ & $\begin{array}{c}{ }^{18} \mathrm{O}- \\
\mathrm{SeO}_{4} \text { Enrichment } \\
\varepsilon_{0}\end{array}$ & $\mathbf{R}^{2}$ & $\begin{array}{c}\text { Rate } \\
\text { coeff. } \\
k\end{array}$ & $\begin{array}{l}\text { Cell- } \\
\text { specific } \\
\text { rate } \\
\text { coef. } \\
k / C D \\
\mathrm{~mL} \mathrm{cell}^{-1}\end{array}$ \\
\hline & & cell/mL & $\mathrm{mM}$ & $\mathrm{mM}$ & $\mathrm{mM} / \mathrm{mM}$ & $\%$ & & $d^{-1}$ & $d^{-1}$ \\
\hline \multicolumn{10}{|c|}{ Suspensions with varying $\mathrm{pH}$} \\
\hline $\mathrm{pH} 6 \mathrm{~A}$ & 6.0 & $1.3 \times 10^{9}$ & 22.0 & 50.0 & 2.3 & $\mathrm{nd}^{a}$ & nd & nd & nd \\
\hline $\mathrm{pH} 6 \mathrm{~B}$ & 6.0 & $1.3 \times 10^{9}$ & 22.4 & 57.0 & 2.5 & $\mathrm{Nd}$ & nd & nd & nd \\
\hline $\mathrm{pH} 7 \mathrm{~A}$ & 7.0 & $2.4 \times 10^{9}$ & 21.4 & 55.0 & 2.6 & $1.6 \pm 1.1$ & 0.82 & 2.1 & $8.6 \times 10^{10}$ \\
\hline $\mathrm{pH} 7 \mathrm{~B}$ & 7.0 & $2.4 \times 10^{9}$ & 21.4 & 55.0 & 2.6 & $2.6 \pm 0.9$ & 0.92 & 2.5 & $1.0 \times 10^{11}$ \\
\hline $\mathrm{pH} 8 \mathrm{~A}$ & 8.0 & $1.3 \times 10^{9}$ & 22.5 & 52.5 & 2.3 & $3.0 \pm 0.6$ & 0.98 & 3.8 & $3.1 \times 10^{11}$ \\
\hline $\mathrm{pH} 8 \mathrm{~B}$ & 8.0 & $1.8 \times 10^{9}$ & 22.4 & 57.0 & 2.5 & $4.2 \pm 0.6$ & 0.98 & 2.0 & $1.1 \times 10^{11}$ \\
\hline $\mathrm{pH} 9 \mathrm{~A}$ & 9.0 & $2.5 \times 10^{9}$ & 21.4 & 54.0 & 2.5 & $4.3 \pm 1.5$ & 0.92 & 2.1 & $5.9 \times 10^{10}$ \\
\hline $\mathrm{pH} 9 \mathrm{~B}$ & 9.0 & $2.5 \times 10^{9}$ & 21.4 & 54.0 & 2.5 & $5.1 \pm 0.4$ & 1.00 & 1.5 & $5.9 \times 10^{10}$ \\
\hline \multicolumn{10}{|c|}{ Suspensions with varying lactate/selenate ratios } \\
\hline L:Se 2.6 & 8.0 & $1.2 \times 10^{9}$ & 19.0 & 50.0 & 2.6 & $3.7 \pm 1.0$ & 0.97 & 1.1 & $9.1 \times 10^{10}$ \\
\hline L:Se 1.5 & 8.0 & $1.1 \times 10^{9}$ & 12.5 & 19.0 & 1.5 & $5.0 \pm 2.0$ & 0.95 & 0.7 & $6.6 \times 10^{10}$ \\
\hline L:Se 1.1 & 8.0 & $1.2 \times 10^{9}$ & 19.0 & 20.0 & 1.1 & $3.8 \pm 0.7$ & 0.99 & 1.1 & $9.7 \times 10^{10}$ \\
\hline L:Se 0.3 & 8.0 & $1.1 \times 10^{9}$ & 17.0 & 4.8 & 0.3 & $5.0 \pm 0.8$ & 0.99 & 1.1 & $9.7 \times 10^{10}$ \\
\hline L:Se 0.2 & 8.0 & $1.4 \times 10^{9}$ & 53.0 & 12.0 & 0.2 & $3.7 \pm 0.7$ & 0.98 & 1.4 & $9.9 \times 10^{10}$ \\
\hline \multicolumn{10}{|c|}{ Suspensions with varying cell density ${ }^{c}$} \\
\hline CD 2.6 & 8.0 & $2.6 \times 10^{9}$ & 19.0 & 54.0 & 2.8 & $5.8 \pm 0.7$ & 0.99 & 3.7 & $1.4 \times 10^{11}$ \\
\hline CD 1.5 & 8.0 & $1.5 \times 10^{9}$ & 19.0 & 54.0 & 2.8 & $5.1 \pm 0.8$ & 0.99 & 1.8 & $1.3 \times 10^{11}$ \\
\hline CD 0.3 & 8.0 & $2.9 \times 10^{8}$ & 19.0 & 54.0 & 2.8 & $4.2 \pm 2.8$ & 0.80 & 0.2 & $7.4 \times 10^{10}$ \\
\hline \multicolumn{10}{|c|}{ Control suspensions } \\
\hline Cntr Se & 8.0 & $4.0 \times 10^{8}$ & 19.5 & 0.0 & $N A^{b}$ & nd & nd & nd & nd \\
\hline Cntr L & 8.0 & $4.0 \times 10^{8}$ & 0.0 & 5.2 & NA & nd & nd & nd & nd \\
\hline $\begin{array}{l}\text { Cntr No } \\
\text { Cells }\end{array}$ & 8.0 & $\mathrm{~N} / \mathrm{A}$ & 29.9 & 31.3 & 1.0 & nd & nd & nd & nd \\
\hline
\end{tabular}

${ }^{a}$ nd $=$ Not determined due to lack of reaction.

${ }^{b} \mathrm{NA}=$ Not applicable.

${ }^{c}$ The data for the suspension labeled "1.2" in Fig. 2a for suspensions with varying cell density is duplicated from suspension L:Se 2.6 here in Table 1. 


\section{List of Figures}
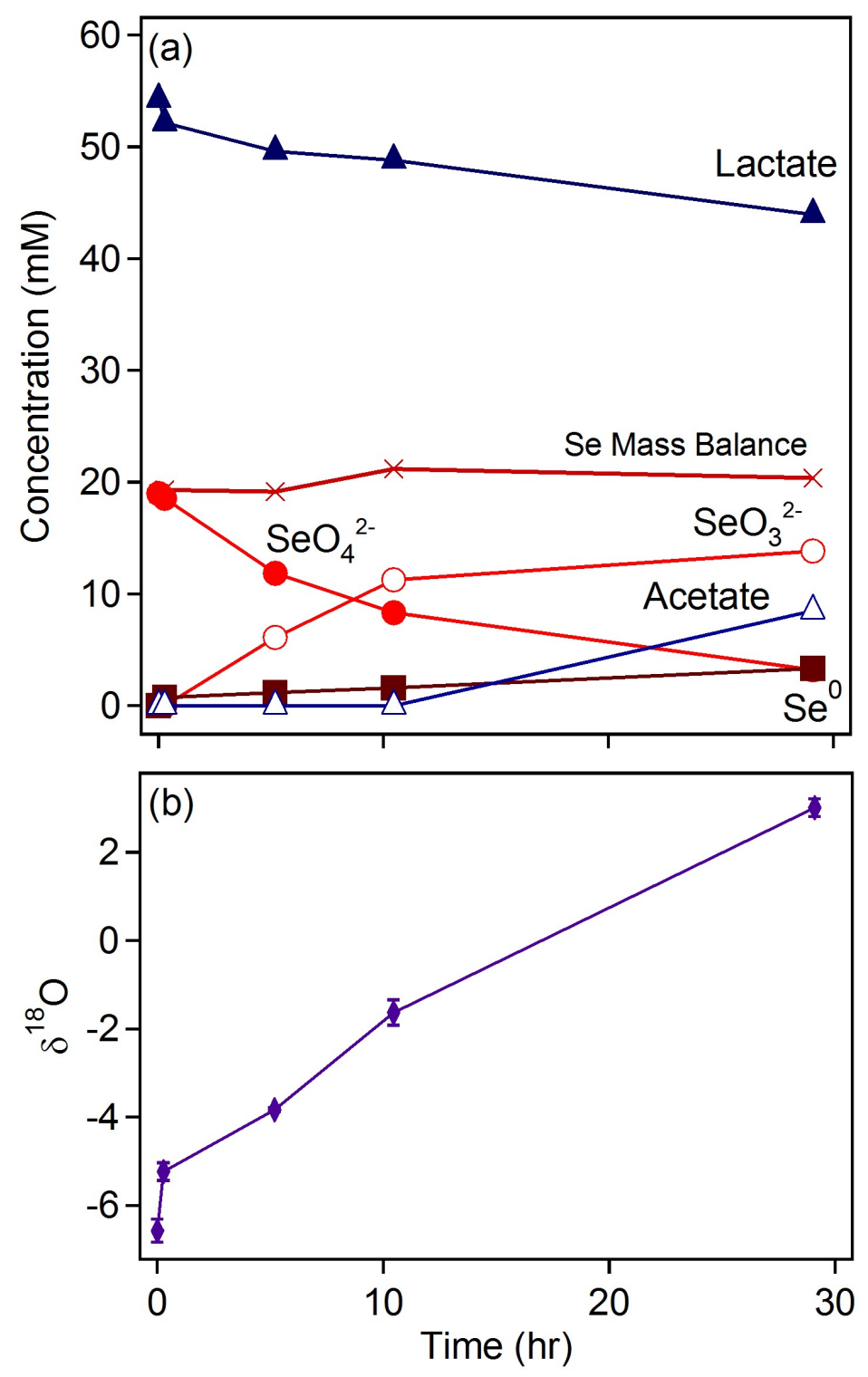

Fig. 1. Kinetic profile for selenate reduction and lactate oxidation by $S$. barnesii (a) and for $\delta^{18} \mathrm{O}$-selenate (b). Data is from suspension "CD 1.5" in Table 1, with the following conditions: $\mathrm{pH} 8.0$, lactate:selenate ratio of 2.8 , cell density $1.45 \times 10^{9} / \mathrm{ml}$. Symbols: selenate (closed circles), lactate (triangles), selenite (open circle), elemental Se (squares), acetate (open triangles), and Se mass balance (x). Error bars for $\delta^{18} \mathrm{O}$, when not visible, are smaller than symbols (diamonds). The early rapid increase in $\delta^{18} \mathrm{O}$ values after $\sim 15$ minutes might have resulted from an error in the initial or second sample preparation or selenate concentration determination 

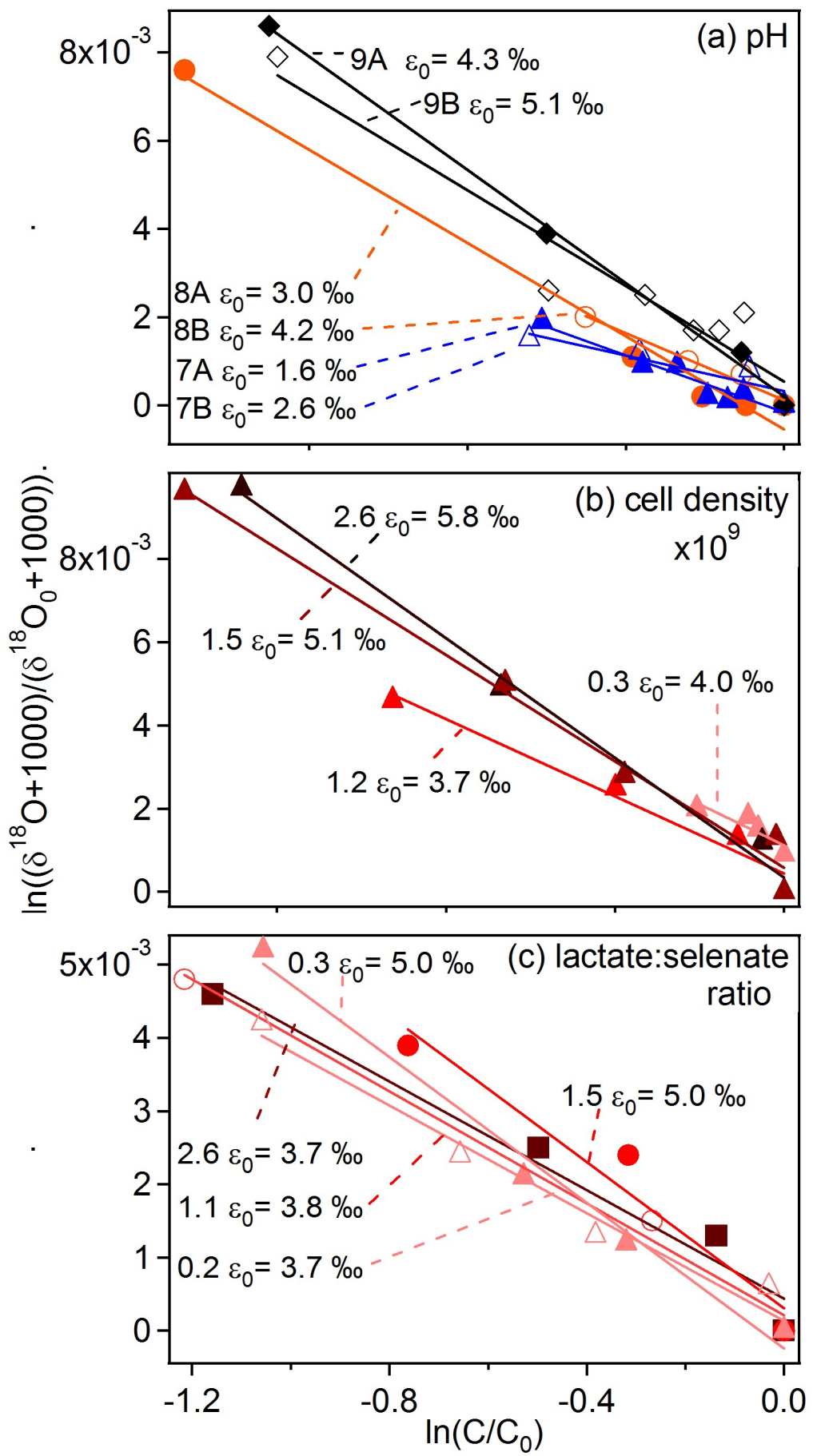

Fig. 2. Linearized ${ }^{18} \mathrm{O}$ enrichment according to equation 1 for the kinetic data in Fig. 3 for cell suspension experiments. (a) Varied $\mathrm{pH}$, where numbers in line labels refer to $\mathrm{pH}$ value and A,B refer to replicate experiments. (b) Varied cell density, where numbers in line labels refer to factor multiplied by $10^{9}$ cells $\mathrm{ml}^{-1}$. (c) Varied lactate:selenate ratio. Symbols correspond to identical ones in Fig. 3. $\varepsilon_{O}$ values were calculated from slopes of regression lines. 

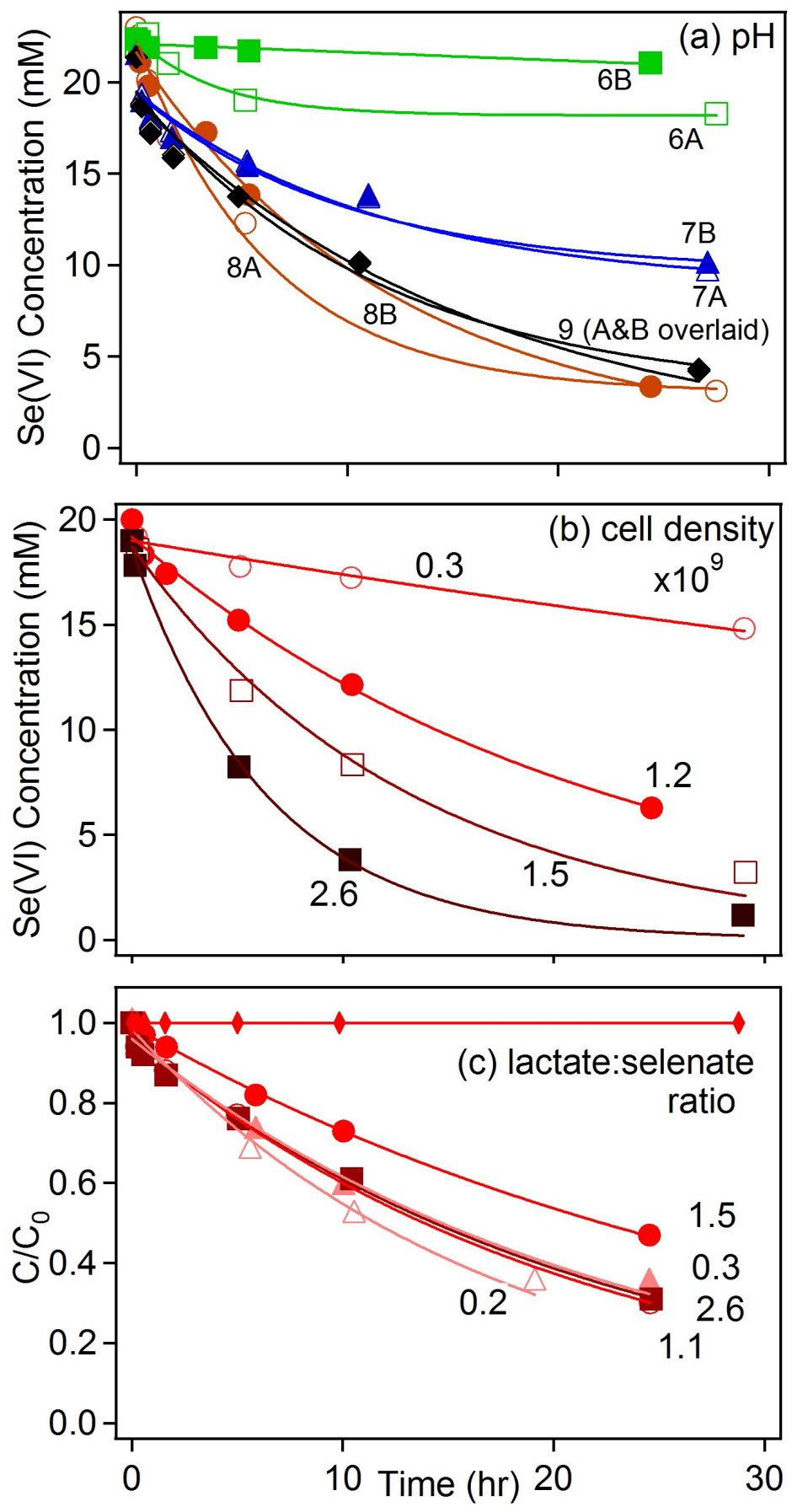

Fig.3. Measured and modeled selenate concentrations over time for different values of (a) $\mathrm{pH}$, (b)cell density at $\mathrm{pH} 8$, and (c) lactate to selenate ratios at $\mathrm{pH} 8$. Initial suspension conditions and modeled first order rate coefficients $\left(k\right.$, converted to units $\left.\mathrm{d}^{-1}\right)$ 
are listed in Table 1. Normalized concentrations are presented in (c) for ease of comparison, but modeled coefficients were obtained with raw data.
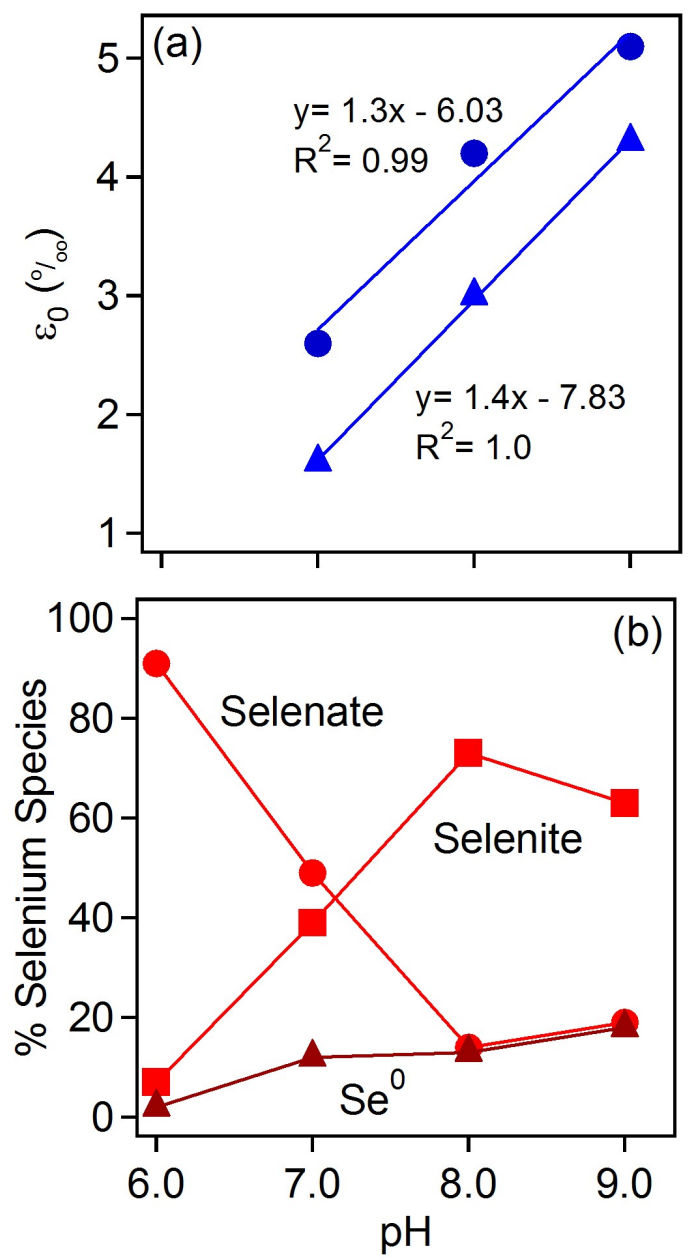

Fig. 4. (a) Relationship of enrichment values $\left(\varepsilon_{0}\right)$ and suspension $\mathrm{pH}$. Triangle symbols refer to suspensions labeled $\mathrm{pH} 7 \mathrm{~A}, 8 \mathrm{~A}$, and $9 \mathrm{~A}$ and were conducted from the same batch of grown cells. Circle symbols refer to suspensions labeled $\mathrm{pH} 7 \mathrm{~B}, 8 \mathrm{~B}$, and $9 \mathrm{~B}$ and were conducted from the same batch of grown cells. All suspensions held similar cell densities and lactate:selenate ratios.(b) Speciation of Se at the end of reaction for suspensions labeled pH 6A, 7A, 8A, 9A. 


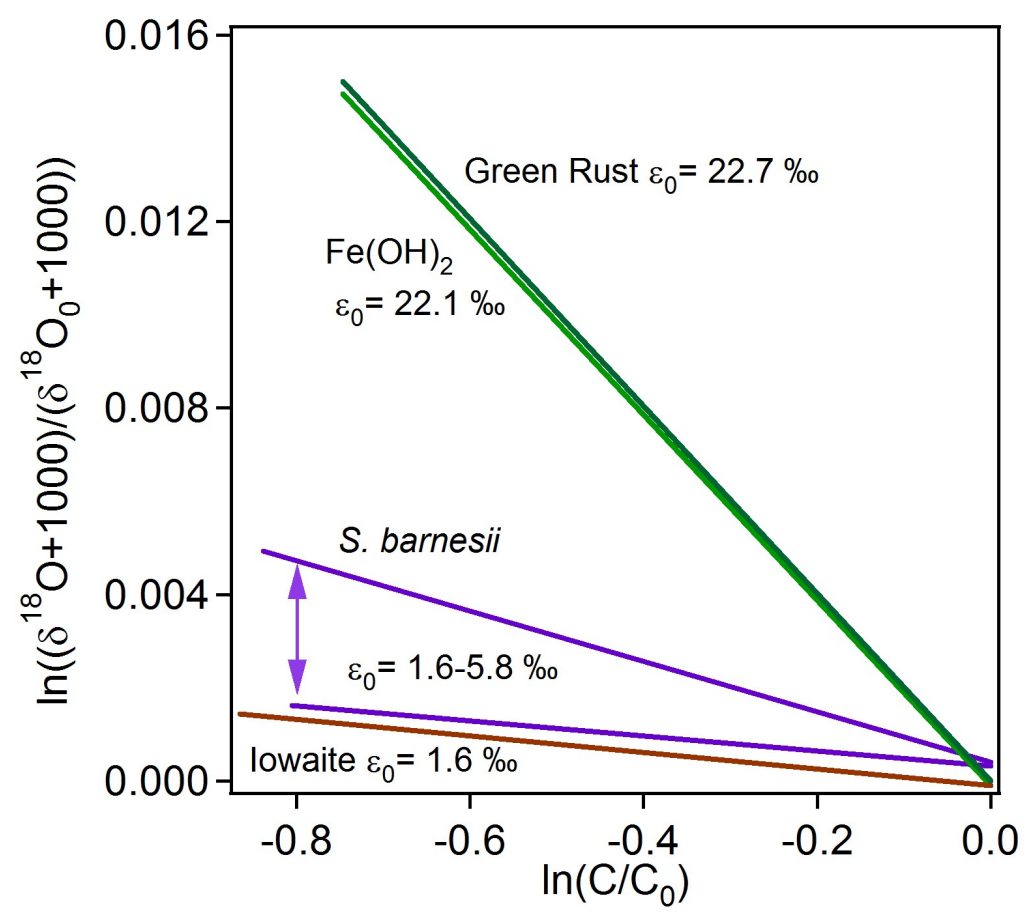

Fig. 5. Comparison of ${ }^{18} \mathrm{O}$ enrichment caused by abiotic and biotic reduction of selenate. The abiotic enrichment values are those measured for chloride green rust and ferrous hydroxide, as well as for uptake without reduction by iowaite (Schellenger and LareseCasanova, 2013). The biotic values are the range measured in this work for S. barnesii. 